\title{
FILOZOFIA POLITYCZNA JAKO POWRÓT DO NATURALNEJ PERSPEKTYWY POJMOWANIA SPRAW POLITYCZNYCH - KONCEPCJA LEO STRAUSSA
}

\author{
POLITICAL PHILOSOPHY AS A RETURN \\ TO NATURAL PERSPECTIVE IN THE UNDERSTANDING \\ OF POLITICAL MATTERS - LEO STRAUSS'S CONCEPTION
}

Marek Pająk*

\begin{abstract}
- ABSTRAKT
Artykuł analizuje podejście Leo Straussa do filozofii politycznej rozumianej jako powrót do naturalnego i zdroworozsądkowego pojmowania spraw politycznych. Koncentruje się na takich Straussowskich kategoriach jak życie polityczne, filozofia i natura. Strauss zwraca uwagę na trudności związane z naukowym rozumieniem „tego, co polityczne" i problemy dotyczące relacji nauki i etyki. Filozofia polityczna jest próbą ponownego odkrycia naturalnej i zdroworozsądkowej perspektywy życia politycznego. Niniejszy tekst jest zarysem Straussowskiej diagnozy.
\end{abstract}

Słowa kluczowe: filozofia polityczna, życie polityczne, natura, Leo Strauss
The paper is an analysis of Leo Strauss's approach to political philosophy seen as a return to natural and common sense understanding of political matters. It focuses on such Straussian categories as political life, philosophy, and nature. Strauss points at difficulties in scientific understanding of "the political" and problems with the relation between science and ethics. Political philosophy is an attempt to rediscover the natural and common sense perspective of the political life. This paper is an outline of Strauss's diagnosis.

Keywords: political philosophy, political life, nature, Leo Strauss

* Uniwersytet Wrocławski, Instytut Politologii. 
Leo Strauss należał do tych filozofów politycznych ubiegłego stulecia, którzy w sposób stanowczy wyrażali obawy o zasadność kierunku dociekań politologicznych w XX wieku (Strauss, 1989a). Jego krytyczne diagnozy stanu zachodniej filozofii politycznej, wątpliwości związane z dominacją scjentystycznej perspektywy w naukach społecznych oraz zwrócenie uwagi na problemy relacji między etyką a poznaniem naukowym nie tracą na aktualności również współcześnie. W dobie sporów dotyczących naukowego poznania spraw politycznych, które wstrząsały politologią w ostatnich dekadach, przypomnienie jego stanowiska i argumentacji może okazać się ożywcze dla dyskusji toczących się na początku XXI wieku. Nobilitacja filozoficzno-politycznej perspektywy w nauce o polityce - odwołującej się do antycznej episteme politike - jest bodaj najbardziej znanym osiągnięciem Straussa. Warto zastanowić się zatem nad składnikami Straussowskiej perspektywy i możliwymi do wyodrębnienia wskazaniami, płynącymi z jego spojrzenia na badanie spraw politycznych.

Strauss to nie tylko wpływowy nauczyciel akademicki, egzegeta klasycznych tekstów filozoficznych, czy też badacz tradycji prawno-naturalnej, ale również krytyk nowożytności i pozytywistycznej perspektywy w naukach społecznych (Strauss, 1965, 1989b, 1989c). Nietrudno zauważyć jednak, że jego osiągnięcia opierają się w znacznej mierze na pracach komentatorskich i krytycznych analizach, czy też polemicznych diagnozach błędnych nurtów intelektualnych współczesności. O wiele większy problem dotyczy pozytywnego wkładu Straussa do współczesnej filozofii politycznej, bowiem niełatwo jest wyodrębnić te elementy jego myśli, które wskazują na właściwy kierunek filozoficzno-politycznych dociekań. Niemniej jednak, abstrahując od sprzecznych sposobów ujmowania pewnych elementów jego koncepcji (zob. Mordarski, 2012), atrakcyjny poznawczo wydaje się ten kierunek interpretacji jego ujęcia filozofii politycznej, który podkreśla znaczenie „powrotu” do naturalnej i zdroworozsądkowej perspektywy oglądu spraw politycznych.

\section{FILOZOFIA POLITYCZNA JAKO ANALIZA „ŻYCIA POLITYCZNEGO”}

Strauss pojmuje filozofię polityczną jako „spójną refleksję prowadzoną przez politycznie usposobionych ludzi, dotyczącą zasadniczych kwestii życia politycznego jako takiego, oraz wysiłek ustanowienia na podstawie takiej refleksji właściwych standardów osądu politycznych działań i instytucji - filozofia polityczna jest próbą odkrycia politycznej prawdy" (Strauss, 2008, s. 152; Strauss, 2007, s. 216). 
Spójność i kompleksowość filozofii politycznej oznacza, że jest ona zorientowana na całość życia politycznego. Innymi słowy, nie dotyczy tylko jednego aspektu spraw politycznych: zachowań wyborczych, polityki partyjnej czy funkcji dystrybucyjnej państwa, lecz odnosi się do relacji między wszystkimi elementami składowymi życia politycznego. Zgodnie ze wskazaniem Arystotelesa, że „rzecz złożoną trzeba rozłożyć aż do jej części niepodzielnych” (Arystoteles, 2006, ks. I 1252a, s. 25) - a to samo odnosi się i do państwa (polis) - podstawową relacją, którą zajmuje się filozofia polityczna, jest stosunek między jednostką (człowiekiem) a wspólnotą polityczną. Jeżeli najlepszym sposobem badania „tego, co polityczne” - według Stagiryty - jest „śledzenie powstawania pewnych stosunków od samego początku"(s. 25), to początkiem refleksji powinno być zawiązywanie się relacji społeczno-politycznych i tworzenie wspólnoty (koinonia). Są to „zasadnicze kwestie życia politycznego".

„Życie polityczne” jest szczególnie ważną kategorią filozofii politycznej Straussa. Filozoficzny ogląd życia politycznego jest „niczym więcej niż w pełni świadomą formą zdroworozsądkowego rozumienia spraw politycznych” (Strauss, 1978, s. 12; Behnegar, 1999, s. 106-111). Wobec tego oznacza ujęcie spraw politycznych z perspektywy indywidualnego podmiotu, jednostkowego „postrzegania” relacji zachodzących we wspólnocie politycznej. Stosowanie powyższego terminu nie implikuje jednak uznania prymatu każdego autonomicznego podmiotu nad zbiorowością, jej celami i konstytuującymi ją zasadami normatywnymi. Strauss widzi życie polityczne jako pewnego rodzaju sieć indywidualnych perspektyw, składających się na zbiorową egzystencję, jako zbiór różnorodnych opinii (doxai) o dobrym życiu i dobrym społeczeństwie. Nie twierdzi jednak, że nie sposób hierarchizować tych perspektyw i wybierać jednych kosztem drugich. Odrzuca tym samym liberalną koncepcję autonomicznych podmiotów, których jednostkowe cele nie podlegają ocenie i hierarchizacji.

Podstawą myśli Straussa jest więc indywidualna perspektywa o charakterze zdroworozsądkowym i potocznym. Refleksja dotyczy „politycznie usposobionych ludzi”, czyli nie-wolnych i równych jednostek w stanie natury, wyabstrahowanych z relacji politycznych - ale tych, którzy są „ludźmi politycznymi”, czyli uwarunkowanymi przez więzy i narracje wspólnotowe. Ponadto Strauss nie sytuuje badacza „tego, co polityczne” poza kontekstem życia politycznego. Innymi słowy podmiot poznania nie jest neutralnym obserwatorem, lecz uczestnikiem życia politycznego i wyniki jego refleksji mają polityczne konsekwencje. Stąd też namysł dotyczy również implikacji tworzonych teorii. „Refleksja” jako „poznanie skierowane na podmiot poznający, mające swe źródło w podmiocie, w przeci- 
wieństwie do poznania rzeczywistości zewnętrznej” (Szymczak i Szkiłądź, 1981, s. 32) jest samopoznaniem sytuacji filozofa (naukowca) jako człowieka i człowieka politycznego (zoon politikon). W pierwszej kolejności jest próbą dotarcia do pierwotnej, ,naturalnej” i potocznej perspektywy oglądu „tego, co polityczne”.

\section{HUSSERLOWSKA PERSPEKTYWA}

Poprzez odwołanie do specyficznie rozumianej klasycznej filozofii politycznej Strauss próbuje zniwelować dystans między naukowym i potocznym spojrzeniem na sprawy polityczne. Rozdźwięk między tymi dwiema perspektywami był i pozostaje przedmiotem żywej dyskusji w nauce i filozofii, przynajmniej od czasów Husserla. Niemniej jednak ma on pewne „naturalne”, czy też „zdroworozsądkowe" źródła. Z jednej strony nauka (jak i filozofia) z perspektywy przeciętnego obywatela - szczególnie gdy nie prowadzi do praktycznych rozwiązań, lecz ma stricte teoretyczny charakter - może wydawać się działalnością bezużyteczną i ekstrawagancką, być przysłowiowym „dzieleniem włosa na czworo". Z drugiej strony przede wszystkim nowożytna nauka, ze szczególnym znaczeniem przypisywanym założeniom epistemologicznym, przez wiele wieków poszukiwała sposobu, w jaki mogłaby odróżnić własną perspektywę od potocznego i zdroworozsądkowego rozumienia rzeczywistości. Wspomniany Husserl uznaje, że błąd, leżący w przesadnym oddzielaniu obu perspektyw, jest ewidentny. „Naturalne poznanie - pisze - zaczyna się wraz z doświadczeniem i pozostaje w obrębie doświadczenia (in der Erfahrung)" (Husserl, 1967, s. 7). „Świat przeżywany" (Lebenswelt), czyli pierwotne, przedteoretyczne i bezrefleksyjne postrzeganie rzeczywistości, stanowi podstawę, która powinna być przedmiotem poznania naukowego (s. 7; Husserl, 1999; Krasnodębski, Nellen i Michalski, 1993; Gniazdowski, 2007; Held, 2003). Strauss wspomina, że to dzięki Husserlowi pojął, iż „wszelkie filozoficzne rozumienie musi zatem rozpoczynać [się - M.P.] od naszego wspólnego rozumienia świata, od naszego rozumienia świata jako zmysłowo postrzeganego uprzednio wobec wszelkiego teoretyzowania" (Strauss, 2012, s. 187).

Połączenie perspektywy filozofa i naukowca z potocznym oglądem spraw politycznych powoduje, że rozdzielenie faktów i wartości staje się nonsensem, natomiast analiza instytucjonalna i proceduralna schodzi na dalszy plan. Przeciętny obywatel nie obserwuje „zjawisk politycznych”, dbając o „neutralne” ustosunkowanie wobec nich, ale postrzega, ocenia i uczestniczy w rzeczywistości. 
Widzi życie polityczne jako całość powiązanych ze sobą elementów, do których - o ile zastanawia się nad swoją sytuacją - ma pewien stosunek emocjonalny, wobec których wyraża opinię albo przyjmuje określoną postawę.

\section{SPRAWY POLITYCZNE SUB SPECIE AETERNITATIS}

Filozofia polityczna ma za zadanie ustanowić „standardy osądu politycznych działań i instytucji”. Wobec tego nie jest to neutralny sposób postrzegania spraw politycznych, pozbawiony wartościowania i oceny moralnej, lecz jest kierowany racjonalnością aksjologiczną, której celem jest „odkrycie prawdy politycznej”. Strauss dodaje, że „filozofia polityczna jest niczym innym jak tylko filozoficznym spojrzeniem na rzeczy polityczne - a »ilozoficzne« oznacza tu sub specie aeternitatis"(Strauss, 2008, 157; Strauss, 2007, 527). Podkreśla zatem filozoficzny charakter refleksji i zaznacza, że jest to ogląd „pod kątem widzenia wieczności (sub specie aeternitatis)"(Lam, 1939, s. 2050). Strauss odwołuje się do łacińskiego zwrotu Spinozy, który pochodzi z dwudziestego trzeciego twierdzenia Etyki. W polskim tłumaczeniu całość brzmi następująco: „Dusza ludzka nie może zostać całkowicie zniszczona wraz z ciałem, lecz pozostaje z niej coś, co jest wieczne" (Spinoza, 2008, s. 357). Spinoza twierdzi dalej, że istota duszy ludzkiej jest wieczna, gdyż została pojęta przez „samą istotę Boga”. Człowiek nie może pamiętać o wieczności, „a jednak pomimo to - pisze Spinoza - czujemy i doświadczamy, że jesteśmy wieczni” (s. 358). Wobec tego dusza trwa o tyle, o ile istnienie ludzkiego ciała jest określone przez czas, ale dusza „posiada też (...) moc określania istnienia rzeczy przez czas i pojmowania ich z punktu widzenia trwania"(s. 358-359).

Filozoficzne myślenie o „tym, co polityczne” oznacza zatem szczególną perspektywę oglądu życia politycznego. Jeżeli ma ono na celu ustanowienie „właściwych standardów osądu”, to musi odwoływać się do „wiecznych” wartości. Innymi słowy „odkrycie prawdy politycznej” nie oznacza jej pojmowania na sposób partykularny i przygodny, jako „prawdy czasów”, ale chodzi o jej wieczną ideę, o prawdę absolutną. Według Straussa tylko perspektywa filozoficzna może zmierzać w stronę horyzontu transcendentnego, poza ograniczenia współczesnych, dominujących trendów, ludzkiej czasowości i skończoności (Zuckert, 2013, s. 53). Filozofia polityczna ma więc pomóc w przekroczeniu granic temporalnych i przygodnych uwarunkowań ładu politycznego. Po pierwsze, nie oznacza tylko czysto deskryptywnej analizy spraw politycznych, ale również ich 
ocenę normatywną. Po drugie, osąd nie polega na odwołaniu do powszechnie wyznawanych wartości i przyjmowanych postaw, ale do hierarchii wartości, która istnieje w sferze transcendentnej. Po trzecie, instytucji i wspólnotowych działań nie ocenia się jedynie z perspektywy skończoności ludzkiego życia, ale wiecznego horyzontu bytowania ludzkiej duszy. Po czwarte, warto również podkreślić, że Strauss nie przesądza finalnego sukcesu poszukiwan „politycznej prawdy”. Mówi o „próbie odkrycia”, „poszukiwaniach”, lecz nie o jej zdobyciu, znalezieniu czy ostatecznym poznaniu.

Powyższa perspektywa może wydać się zastanawiająca. Dlaczego Strauss tak znacząco rozszerza analizę spraw politycznych i łączy ją z wymiarem etycznym oraz horyzontem wieczności? Według niego analiza „tego, co polityczne” nigdy nie ogranicza się do prostego opisu działań i instytucji, lecz dotyczy całości życia politycznego. Tymczasem każde wspólnotowe działanie, nawet bezrefleksyjnie, jest nakierowane na cel. Jest nim albo zmiana istniejącego stanu rzeczy, albo jego zachowanie. Jeśli człowiek ma na myśli jedno z powyższych, to nieuchronnie przyjmuje „pewną koncepcję lepszego i gorszego”. Początkowo ma ona charakter opinii (doxa), ale gdy zostanie zakwestionowana, pojawia się chęć zdobycia prawdziwej, niepodważalnej wiedzy (episteme). W taki sposób człowiek kieruje się ku idei dobra (Strauss, 1998, s. 61-62).

Najwyższym dobrem politycznym jest dobre społeczeństwo, które jest celem życia politycznego. Filozofia polityczna pojawia się natomiast wtedy, gdy „ludzie uczynią zdobycie wiedzy o dobrym życiu i dobrym społeczeństwie swym jasno sformułowanym celem" (Strauss 1998, s. 62). Filozofia polityczna jest zatem nieustannym poszukiwaniem wiedzy o dobrym życiu i społeczeństwie. Filozofowie polityczni są tymi, którzy wybierają specyficzny sposób życia - życie kontemplacyjne (vita contemplativa). Nie jest to tylko chwilowa zaduma nad problemami politycznymi lub też zainteresowanie tym czy innym aspektem życia zbiorowego. Jest to natomiast pełne poświęcenie się poszukiwaniu wiedzy o właściwym życiu w wymiarze indywidualnym i zbiorowym. Tym samym jest to nieustanne pytanie o cel wspólnoty politycznej. 


\section{FILOZOFIA POLITYCZNA JAKO NAUKA „NACZELNA I NAJBARDZIEJ KIEROWNICZA"}

Temat filozofii politycznej jest tożsamy z celami politycznego działania, a są nimi „wielkie cele ludzkości: wolność i rząd albo imperium; cele, które potrafią wynieść wszystkich ludzi ponad poziom ich biednych osobowości"(Strauss, 1998, s. 62). Mają one charakter wspólnotowy. Uczestnictwo w życiu politycznym jest tym, co wynosi człowieka ponad jego przeciętność - w pewien sposób dotyka on spraw wiecznych, gdyż działania wspólnotowe niejednokrotnie przekraczają swoim horyzontem długość trwania życia ludzkiego. Spojrzenie filozoficzne na sprawy życia zbiorowego ma ponadczasowy charakter, gdyż tematy polityczne są tymi, które nie ograniczają się jedynie do ludzkiej, materialnej egzystencji. Wspólnotowe więzi nadają perspektywom jednostkowym trwały i - przekraczający ludzką (przemijającą) kondycję - charakter. We wspólnocie politycznej konstytuuje się to, co pozwala człowiekowi skierować się w stronę „punktu widzenia wieczności”, to znaczy od opinii do wiedzy o dobrym życiu (indywidualnym i wspólnotowym). Strauss implicite zdaje się odwoływać do antycznego i przedchrześcijańskiego pojmowania nieśmiertelności, zgodnie z którym uznawano znaczenie zasług dla ojczyzny jako warunku osiągnięcia wiecznej pamięci. Perykles - według relacji Tukidydesa - mówił o bohaterach, iż ci, „oddając (...) życie dla dobra wspólnej sprawy, zyskiwali nieprzemijającą sławę i najwspanialszy pomnik - nie ten grobowiec, w którym spoczywają, lecz pamięć ludzką, dzięki której żyje ich sława, ilekroć słowa lub czyny dadzą do tego sposobność" (Tukidydes, 2003, ks. II 43, s. 108).

Znaczenie życia wspólnotowego powoduje, że jego intelektualna analiza zostaje uznana za o wiele ważniejszą niż w potocznym, współczesnym rozumieniu. Jak pisze Strauss - „W swej pierwotnej formie filozofia polityczna w szerokim rozumieniu jest podstawą wszelkiej filozofii, lub raczej »filozofią pierwszą"” (Strauss, 1978, s. 20). Strauss nadaje więc nauce o polityce rolę, o której pisał Arystoteles jako o „naczelnej i najbardziej kierowniczej”, gdyż dotyczy umiejętności, „które najwyżej cenimy” i „rozstrzyga o tym, co należy czynić, a czego zaniechać”. Strauss podąża drogą Stagiryty, łącząc naukę o polityce z „najwyższym dobrem człowieka”. W odróżnieniu od powszechnie przyjmowanej interpretacji myśli Arystotelesa (por. Leśniak, 1987, s. 47-52), Strauss twierdzi, że to nie metafizyka, lecz filozofia polityczna była najistotniejszą dziedziną dla filozofów antycznych od czasów Sokratesa. Klasyczni filozofowie mieli świadomość znaczenia politycznego aspektu ich działalności. Stąd też życie polityczne stanowiło ważny przedmiot ich zainteresowań. 


\section{PROBLEMY NOWOŻYTNEJ NAUKI O POLITYCE}

„Powrót” do klasycznej filozofii politycznej oznacza przede wszystkim zwrócenie się w stronę subiektywnych obrazów rzeczywistości. Ma stanowić receptę na bolączki nowożytnej nauki o polityce. Jedną z nich jest oddzielenie perspektywy naukowej od potocznego i zdroworozsądkowego postrzegania świata. Filozofia polityczna jest idealnym narzędziem kuracji, gdyż „jest tym działem filozofii, który jest najbliższy życiu politycznemu, życiu ludzkiemu” (Strauss, 1989, s. 62). Problem nowożytnej filozofii politycznej wynika z tego, że wraz z rozwojem filozofii politycznej wytworzyła się tradycja, która oddaliła filozofów od życia politycznego. Po pierwsze, powstały idee i koncepcję, które ukształtowały nowy świat i nowe społeczeństwa. Po drugie, ludzka percepcja politycznego „świata przeżywanego" również została zmodyfikowana pod wpływem tradycji filozofii politycznej. Innymi słowy człowiek zatracił perspektywę naturalną, która była jeszcze dostępna klasykom. Platon i Arystoteles nie znali wielu współczesnych pojęć, jak i nie posiedli wiedzy zgromadzonej we współczesnych bibliotekach. Jeszcze Leibniza można było określać mianem polihistora. Przyrost wiedzy - czy też raczej różnorodnych opinii - spowodował, że współczesne postrzeganie „tego, co polityczne" jest widzeniem przez pryzmat tradycji filozofii politycznej (Strauss, 1989b, s. 59). Żeby przywrócić nauce naturalny ogląd spraw politycznych, trzeba zarówno odwołać się do indywidualnych ludzkich perspektyw, jak i do klasycznych fundamentów nauki o polityce. Za pomocą tych ostatnich będzie można oddzielić to, co we współczesnym indywidualnym postrzeganiu jest wytworem tradycji filozofii politycznej (oraz ideologii), od tego, co może zbliżyć współczesnego człowieka do poznania naturalnego.

Bliski kontakt klasyków z życiem politycznym oznaczał, że nie rozpoczynali jego analizy od takich dystynkcji, jak rozróżnienie między „stanem natury” i „społeczeństwem obywatelskim”, „faktami” i „wartościami” czy „rzeczywistością" i „ideologiami”. Stawiali pytania, które były przedmiotem dyskusji na zgromadzeniach i radach. Wznosili je - jak twierdzi Strauss - „w sposób zrozumiały i bezpośredni”, dostępny „z perspektywy codziennego doświadczenia i codziennego użytku" (Strauss, 1989b, s. 61). Słowem, język klasycznej filozofii nie był niezrozumiały dla przeciętnego obywatela, miał zarówno poruszać problemy mu znane, jak i artykułować je w sposób dla niego - na ile to możliwe zrozumiały. Nie przypominał technicznego żargonu, jego autorzy nie próbowali koniecznie stworzyć nowych kategorii opisu rzeczywistości. Robili to dopiero wtedy, gdy nie odnajdywali sposobu na odpowiednią artykulację problemów 
przy pomocy języka potocznego. Nie mnożyli bytów bez potrzeby. Nie oznacza to jednak, że nauka o polityce miała być dla klasyków tylko uzasadnieniem zdroworozsądkowych przekonań. Analiza była rozpoczynana w świecie przygodnych i różnorodnych opinii o właściwym życiu politycznym, posługiwano się ich językiem i odwoływano się do potocznego oglądu problemów. Był to jednak początek filozoficznej drogi ku „politycznej prawdzie”, konieczny, by nie stracić z oczu zagadnień istotnych z perspektywy obywatelskiej, aby nie budować - jak nowożytna nauka o polityce - kolejnej jaskini pod platońską (Strauss, 1988, s. 155).

\section{FILOZOFICZNA PERSPEKTYWA JAKO „WZMOCNIENIE” ZDROWEGO ROZSĄDKU}

Strauss twierdzi, że każdy dorosły człowiek „posiada w pewnym stopniu wiedzę polityczną. Każdy wie coś o podatkach, policji, prawie, więzieniach, wojnie, pokoju, zawieszeniu broni. Każdy wie, że celem wojny jest zwycięstwo, że wojna wymaga ofiary najwyższej i wielu innych wyrzeczeń, że odwaga zasługuje na pochwałę, a tchórzostwo na naganę. Każdy wie, że kupowanie koszuli, w przeciwieństwie do oddawania głosu, nie jest samo w sobie działaniem politycznym". W zdrowym rozsądku i potocznym rozumieniu spraw politycznych leży więc istota pojmowania „tego, co polityczne”. Ewidentnie ma ono wartościujący charakter. Dyskusje na agorze nie przypominają pozbawionych emocji debat o właściwościach obiektów fizycznych (Strauss, 1998, s. 62). Jeśli celem nauki o polityce mają być tematy będące przedmiotem sporów politycznych, to z perspektywy Straussowskiej pytanie o równowagę systemu politycznego i jego determinantów ma sens tylko wtedy, gdy dotyczy konkretnych propozycji wysuwanych w debacie publicznej. Nie może przypominać badania na kształt analizy zjawisk przyrodniczych. Z drugiej strony, intensywność sporów politycznych, różnorodność i kolizyjność opinii sprawia, że zdrowy rozsądek nie wystarcza we właściwym wyborze dobrego życia. Ponadto ideologiczny charakter nowożytności powoduje, że jednostki nie są w stanie przeciwstawić się radykalnym ideom. Strauss podkreśla, iż „doświadczenie wydaje się pokazywać, że zdrowy rozsądek pozostawiony samemu sobie nie jest dowodem przeciwko tym ekstremizmom" (Strauss, 2007, s. 528). Należy pamiętać, że pisze to człowiek, który jako obywatel obserwował wzrost fanatycznych nastrojów w Republice Weimarskiej. Stąd też zaznacza, że „zdrowy rozsądek potrzebuje wzmocnienia przez filozofię 
polityczną" (s. 528). Wobec tego do właściwego badania „tego, co polityczne” potrzebna jest filozoficzna refleksja nad naturą spraw politycznych. Zdrowy rozsądek w dobie późnej nowożytności wymaga zatem wzmocnienia przez refleksję filozoficzną. Filozofia polityczna ma pomóc w odzyskaniu naturalnej perspektywy oglądu „tego, co polityczne”. Innymi słowy, ma umożliwić powrót do „fundamentalnych pytań” życia politycznego, które nowożytna nauka zastąpiła „pytaniem o metodę" (Strauss, 1989b, s. 63).

Strauss twierdzi, że zwrócenie filozofii w stronę naturalnej perspektywy człowieka nie było w istocie dziełem Husserla. Husserl powrócił tylko do Sokratejskiego rozumienia filozofii. Stwierdzenie Cycerona, iż to Sokrates sprowadził filozofię z nieba na ziemię, rozjaśnia argumentację Straussa. Sokrates bowiem „widział człowieka w świetle tajemniczej natury całości. Sądził tym samym, że lepiej znamy sytuację człowieka jako człowieka niż ostateczną przyczynę tej sytuacji" (Strauss, 1998, s. 90). Słynny Ateńczyk zatem był otwarty na - mówiąc językiem Erica Voegelina - „tajemnicę ludzkiej egzystencji” (Voegelin, 1992, s. 37). Stąd też porzucił pytanie Talesa o arché, zwrócił się w stronę człowieka i odtąd filozofia trafiła „pod strzechy”. Innymi słowy przedłożył dociekania o naturze człowieka nad te, dotyczące struktury wszechświata, jego przyczyny i celu, czyli odnoszące się do „całości” bytu. Są to prawdziwe źródła filozofii politycznej, a Sokrates dla Straussa jest pierwszym z poszukujących politycznej mądrości. Istotne jest również to, że Sokrates, sprowadzając filozofię na ziemię, wrócił do potocznego postrzegania świata przez człowieka. Znajomość sytuacji człowieka oznacza, że mamy świadomość ludzkiej kondycji, ale nie znamy jej przyczyny. Innymi słowy możemy poszukiwać wiedzy o tym, kim jesteśmy i w jaki sposób postrzegamy świat, lecz znacznie trudniej jest nam pytać o to, „skąd przychodzimy”. Filozoficzne pytanie o istotę życia politycznego oznacza zatem próbę poszukiwania ludzkiej natury.

Stąd też Sokrates - pytając o naturę człowieka - widział go „w świetle niezmiennych idei, to znaczy fundamentalnych i stałych problemów. Nazwać sytuację człowieka oznacza wypowiedzieć jego otwartość na całość" (Strauss, 1998, s. 90). Człowiek - jako istota śmiertelna i biologicznie uwarunkowana, ale zarazem myśląca, samoświadoma i tworząca dzieła trwające wiele pokoleń - pozostaje w sytuacji „zawieszenia” pomiędzy biologicznymi i czasowymi ograniczeniami a tajemnicą wieczności. Dlatego też do pełni człowieczeństwa konieczne jest otwarcie na „całość”. „Otwartość na całość” oznacza poszukiwanie kontaktu z wiecznością, transcendencją - szukanie ludzkiej natury. Strauss twierdzi, że odkrycie natury oznacza początek filozofii (Strauss, 1965, s. 82). Kon- 
cepcja natury ma pochodzenie stricte filozoficzne, nie oddaje jej żadna kategoria biblijna. Pojawia się po raz pierwszy u Greków - w Odysei Homera - gdy bóg Hermes, aby ochronić Odyseusza przed czarami Kirke, wyrywa z ziemi ziele i pokazuje mu jego naturę. Ziele ma chronić Odyseusza przed czarami. Hermes z łatwością wyrywa je i podaje herosowi, gdyż zna jego naturę. „Natura oznacza więc właściwości danej rzeczy lub danego rodzaju rzeczy; to, jak dana rzecz lub rodzaj wygląda i sposób, w jaki działa, przy czym owej rzeczy bądź rodzaju nie stworzyli ani bogowie, ani człowiek" (Strauss, 2010, s. 10).

To, co naturalne, jest zatem przeciwieństwem artefaktów tworzonych przez człowieka, jak i wytworów boskich. Grecka koncepcja natury danej rzeczy zwraca uwage, przede wszystkim, na jej „wzrastanie”, czyli to, do jakiego celu zmierza, jakie właściwości posiada rzecz w pełni rozwinięta. Wobec tego natura ludzka jest tym, do czego człowiek dąży, aby osiągnąć doskonałość (eudajmonia), oznacza cel dobrego życia w wymiarze wspólnotowym i indywidualnym. Otwartość na całość oznacza, że cel należy postrzegać w perspektywie „wieczności”: ponadhistorycznej, zhierarchizowanej i wartościującej, przekraczającej ograniczenia ludzkiej kondycji (indywidualne i wspólnotowe) i skończoność jednostkowego życia.

Koncepcję natury można również przedstawić, sięgając do jej przedfilozoficznych źródeł. W Natural Right and History Strauss opisuje sytuację dawnego podróżnika, który odwiedzając różne kraje, zostaje skonfrontowany z wieloma odmiennymi sposobami myślenia o sprawach politycznych, zwyczajami i zasadami prawa. Wszystkie one mają uświęcony tradycją charakter i są uznawane za właściwe przez konkretne wspólnoty. Podróżnik uświadamia sobie różnicę między tym, co jest niezaprzeczalnie najlepsze, a tym, co jest dziełem konwencji. Innymi słowy podróżnik zauważa, że niekoniecznie to, co uznawane za właściwe przez wspólnotę, musi być takie w rzeczywistości. Ponadto taka konstatacja nie naraża go na odrzucenie przez współobywateli, gdyż odnosi ją nie do wspólnoty, w której egzystuje, lecz do odległych krain. W taki sposób pojawia się rozróżnienie między tym, co dobre, a tym, co tradycyjne. Początkiem tej dystynkcji jest jednak jednostkowe jej „dostrzeżenie”, sprzeciwiające się „pogłosce” czy utartej opinii o uświęconym charakterze jednej z wielu tradycji. Podróżnik jest metaforycznym przedstawieniem filozofa, który odtąd może ustanowić rozróżnienie między partykularnymi perspektywami różnorodnych zbiorowości a spojrzeniem „naturalnym” (Strauss, 1965, s. 86-87). Powyższy opis wskazuje na dwa wymiary pojmowania natury przez Straussa. Z jednej strony oznacza ona artykulację wiecznego porządku, sposób przejawiania się „całości” i właściwy 
cel poszczególnych bytów. Z drugiej strony jest to „naturalny” standard dla przedfilozoficznego rozumienia rzeczywistości, to znaczy, że filozoficzną koncepcję natury można wyprowadzić z pierwotnego („naturalnego”) postrzegania otoczenia. Wobec tego natura jest swoistym pomostem między zdroworozsądkową a filozoficzną perspektywą oraz między ludzką kondycją a „wiecznym porządkiem” („całością”). Te jej dwa wymiary zostały ukazane najpełniej przez filozofię (Mordarski, 2012, s. 12).

\section{PODSUMOWANIE}

Koncepcję Straussa można zatem postrzegać jako próbę nobilitacji filozoficzno-politycznej perspektywy, rozumianej jako obrona zdroworozsądkowego spojrzenia na sprawy polityczne. Została ona zbudowana wyraźnie w opozycji do dominującego, scjentystycznego ujęcia w naukach społecznych, którego Strauss był zagorzałym przeciwnikiem. Pomimo enigmatycznego charakteru jego koncepcji, trudno odmówić jej cennego waloru krytycznego wobec utartych opinii dotyczących poznania naukowego. Ponadto Strauss był jednym z pierwszych, którzy zwrócili uwagę na problem rosnącego „bagażu” metodologicznego nauk społecznych. Rozrost aparatu pojęciowego, lekceważenie istoty badanego przedmiotu kosztem dysput metodologicznych stały się, jego zdaniem, głównym problemem nauk społecznych. W dobie - spowodowanej rewolucją informacyjną - istnej eksplozji publikacji, projektów badawczych i analiz, których poziom naukowy jest bardzo zróżnicowany, można stwierdzić, że jego spostrzeżenia miały charakter profetyczny.

Ponadto autor Natural Right and History przypisuje nauce o polityce - pojmowanej na sposób klasycznej episteme politike - fundamentalną i naczelną rolę pośród innych dyscyplin naukowych. Jest to zarówno jej nobilitacja, jak i wyzwanie dla wszystkich zajmujących się analizą spraw politycznych. Strauss nie tylko widzi w filozofii politycznej narzędzie poszukiwania celów zbiorowości, ale przede wszystkim jest to „wzmocnienie” zdrowego rozsąadku, swoista bariera ochronna przed ideologizacją sfery publicznej. Tym samym zwraca uwagę na związek między upadkiem filozofii politycznej i kryzysem politycznym, którego najbardziej wyraźnym świadectwem było, jego zdaniem, zwycięstwo nazistowskiej tyranii w Niemczech lat trzydziestych ubiegłego wieku. „Najważniejsze wydarzenie roku 1933 - pisze Strauss - dowiodło raczej, jeśli taki dowód był potrzebny, że człowiek nie może porzucić pytania o dobre społeczeństwo 
i uwolnić się od odpowiedzialności od znalezienia na nie odpowiedzi przez odwołanie do Historii czy jakiejkolwiek siły innej niż jego rozum" (Strauss, 1989, s. 78). Perspektywa Straussa nie pozwala zapomnieć o nieustannej potrzebie rozważania i obrony normatywnych uwarunkowań ładu politycznego, o zawsze istniejącej możliwości ponownego pojawienia się totalitaryzmu.

Przypomnienie perspektywy Straussa może być owocne również dla dyskusji dotyczących statusu normatywnego teoretyzowania w nauce o polityce (Brown, 2004, s. 103-123; Kaufman-Osborn, 2010; Brown, 2010; Gunnell, 2010; Kasza, 2010; Dryzek, Honig i Phillips, 2006, s. 10-11; Beyme, 2007, s. 61-63, 76-78). Spór o miejsce normatywnej teorii pośród innych subdyscyplin politologicznych, zasadność jej oddzielenia od głównych podejść w nauce o polityce to tematy, które nurtują politologów zarówno dziś, jak i w połowie ubiegłego wieku. Filozofia polityczna Straussa z pewnością nie jest odpowiedzią na wszelkie problemy naukowego poznania spraw politycznych, ale niewątpliwie pozwala spojrzeć z innej perspektywy na dylematy, które stale towarzyszą badaniu „tego, co polityczne".

\section{BiBLIOGRAFIA}

Arystoteles (2006). Polityka. Warszawa: Wydawnictwo Naukowe PWN.

Arystoteles (2011). Etyka nikomachejska. Warszawa: Wydawnictwo Naukowe PWN.

Behnegar, N. (1999). The Intellectual Legacy of Leo Strauss (1899-1973). Annual Review of Political Science 2, 95-116.

Beyme, K. (2007). Współczesne teorie polityczne. Warszawa: Wydawnictwo Naukowe Scholar.

Brown, W. (2004). At the Edge. W: What is Political Theory. W: White, S.K., Moon, D.J. (red.). London - Thousand Oaks - New Delhi: SAGE Publications.

Brown, W. (2010). Political Theory is Not a Luxury: A Response to Timothy Kaufman-Osborn „Political Theory as a Profession”, Political Research Quarterly, 63 (3), 680-85.

Dryzek, J.S., Honig, B., Phillips, A. (red.). (2006). The Oxford Handbook of Political Theory. Oxford: Oxford University Press.

Gniazdowski, A. (2007). Polityka i geometria: fenomenologia Edmunda Husserla a problem demokracji. Warszawa: Wydawnictwo IFiS PAN.

Gunnell, J.G. (2010). Professing Political Theory, Political Research Quarterly, 63 (3), 674-79.

Held, K. (2003). Fenomenologia świata politycznego. Warszawa: Wydawnictwo IFiS PAN. Homer (2000). Odyseja. Gdańsk: Tower Press.

Husserl, E. (1999). Kryzys nauk europejskich i fenomenologia transcendentalna. Toruń: Rolewski. 
Husserl, E. (1967). Idee czystej fenomenologii i fenomenologicznej filozofii. Warszawa: Państwowe Wydawnictwo Naukowe.

Kasza, G.J. (2010). The Marginalization of Political Philosophy and Its Effects on the Rest of the Discipline, Political Research Quarterly, 63 (3), 697-701.

Kaufman-Osborn, T.V. (2010). Political Theory as a Profession and as Subfield, Political Research Quarterly, 63 (3), 655-73.

Krasnodębski, Z., Nellen, K., Michalski, K. (red.). (1993). Świat przeżywany: fenomenologia i nauki społeczne. Warszawa: Państwowy Instytut Wydawniczy.

Lam, S. (red.). (1939). Encyklopedyczny słownik wyrazów obcych: pochodzenie wyrazów, wymowa, objaśnienia pojęć, skróty, przysłowia, cytaty. Warszawa: Księgarnia Wydawnicza Trzaski, Everta i Michalskiego S.A.

Leszczyński, D. (2011). Zdrowy rozsądek i sceptycyzm, Studia Philosophica Wratislaviensia, $\operatorname{LIX}(1), 5-34$.

Leśniak, K. (1989). Arystoteles. Warszawa: Wiedza Powszechna.

Meier, C. (2012). Powstanie polityczności u Greków. Warszawa: Fundacja Świętego Mikołaja - Redakcja „Teologii Politycznej”.

Monroe, K.R. (red.). (2005). Perestroika!: The Raucous Rebellion in Political Science. New Haven-London: Yale University Press.

Mordarski, R. (2007). Klasyczny racjonalizm polityczny w ujęciu Leo Straussa. Bydgoszcz: Wydawnictwo Uniwersytetu Kazimierza Wielkiego.

Mordarski, R. (2012). Leo Strauss a problem teologiczno-polityczny. W: L. Strauss, Jerozolima i Ateny: oraz inne eseje z filozofii politycznej. Kęty: Wydawnictwo Marek Derewiecki.

Schram, S., Caterino, B. (red.). (2006). Making Political Science Matter: Debating Knowledge, Research, and Method. New York: New York University Press.

Spinoza, B. (2008). Etyka: w porządku geometrycznym dowiedziona. Warszawa: Wydawnictwo Naukowe PWN.

Strauss, L. (1965). Natural Right and History. Chicago-London: University of Chicago Press.

Strauss, L. (1978). The City and Man. Chicago-London: University of Chicago Press.

Strauss, L. (1988). Persecution and the Art of Writing. Chicago-London: The University of Chicago Press.

Strauss L. (1989a). An Epilogue. W: Liberalism Ancient and Modern. Ithaca-London: Cornell University Press.

Strauss, L. (1989b). On Classical Political Philosophy. W: An Introduction to Political Philosophy: Ten Essays by Leo Strauss, zredagowane przez Hilail Gildin. Detroit: Wayne State University Press.

Strauss, L. (1989c). The Three Waves of Modernity. W: An Introduction to Political Philosophy: Ten Essays. Wayne State University Press.

Strauss, L. (1989d). What Is Political Philosophy? W: An Introduction to Political Philosophy: Ten Essays. Wayne State University Press.

Strauss, L. (1998). Czym jest filozofia polityki? W: Sokratejskie pytania: eseje wybrane, przetłumaczone przez Paweł Maciejko. Warszawa: Fundacja Aletheia. 
Strauss, L. (2007). What Can We Learn from Political Theory?, Review of Politics, 69 (4): 515-529.

Strauss, L. (2008). Czego uczy nas teoria polityczna, Przeglad Polityczny, $n r 87$.

Strauss, L., Cropsey, J. (2010). Historia filozofii politycznej. Warszawa: Fundacja Augusta hr. Cieszkowskiego.

Strauss, L., Voegelin, E. (2004). Faith and Political Philosophy: The Correspondence Between Leo Strauss and Eric Voegelin, 1934-1964. Columbia-London: University of Missouri Press.

Szymczak, M., Szkiłądź, H. (red.). (1981). Słownik języka polskiego, t. 3, R-Ż. Warszawa: Państwowe Wydawnictwo Naukowe.

Tukidydes (2003). Wojna peloponeska. Warszawa: Czytelnik.

Voegelin, E. (1992). Nowa nauka polityki. Warszawa: Fundacja Aletheia.

Zuckert, C.H. (2013). Political Philosophy and History. W: R. Major (red.) Leo Strauss's Defense of the Philosophic Life: Reading What is Political Philosophy. Chicago-London: The University of Chicago Press. 